Jerzy Walachowicz

\title{
Advocatia dicta gharde w XIV w.?
}

\section{Advocatia dicta gharde im XIV Jahrhundert?}

1. Wstęp. 2. Wykorzystane źródła: 2.1. Wykaz książęcych dochodów z Rugii (1314 r.); 2.2. Spis dochodów biskupich (1318 r.); 2.3. Lustracja nowomarchijska Ludwika I Starszego (1337 r.). 3. Askańska reorganizacja zarządu terytorialnego. 4. Władze lokalne na Pomorzu Zachodnim. 5. Wnioski.

1. Vorwort. 2. Benutzte Quellen: 2.1. Das Register der Fürsteneneinkommen von Rügen (1314); 2.2. Das Verzeichnis der Bischofseinkommen (1318); 2.3. Das neumärkische Landbuch norkgraf Ludwig's des Älteren (vom Jahre 1337). 3. Askanische Reorganisation der Landesverwaltung. 4. Lokalbehörden in Pommern. 5. Schlussfolgerungen.

1. W literaturze naukowej często i nie bez racji akcentuje się burgwardę, jako okręg charakterystyczny dla terytoriów zachodniosłowiańskich ulegających ekspansji niemieckiej. Wzmacnial on najbliższą okolicę przed ewentualnym niebezpieczeństwem, dla ludności zaś stanowił lokalne centrum wspólnych spraw ${ }^{1}$. Występowal głównie we wczesnym średniowieczu. Czy mógl istnieć także później, np. w XIV w.? Spróbujmy odpowiedzieć na to pytanie.

2. Kwerenda źródłowa, dotycząca struktur zarządu terytorialnego na terenach północno-zachodniej Słowiańszczyzny, zwłaszcza na odcinku księstwa Wisławów rugijskich i marchii brandenburskiej trans Oderam w okresie askańskim pozwoliła zaobserwować pewne zmiany $w$ organizacji władzy $w$ terenie. W niniejszym artykule pragnę zwrócić szczególnie uwagę na trzy dokumenty, przypominające lustracje $i$ wielce przydatne dla badań nad zarządem terenowym. Są to: wykaz dochodów książęcych, sporządzony przez rycerza

\footnotetext{
${ }^{1}$ W. Pode $\mathrm{h} 1$, Burg und Herrschaft in der Mark Brandenburg, Untersuchungen zur mittelalterlichen Verfassungsgeschichte unter besonderer Berücksichtigung von Altmark, Neumark und Havelland, Mitteldeutsche Forschungen, Bd. 76, Köln-Wien 1975, s. 455-465 i in.
} 
z Brunświku dla Rugii z 11 listopada 1314 r. $^{2}$; wykaz rocznych dochodów $\mathrm{z}$ tej wyspy biskupa $\mathrm{z}$ Roeskilde, ujęty $\mathrm{w}$ dwóch punktach rzymskich, pochodzący $\mathrm{z}$ około 1318 r. i obejmujący w pierwszym tzw. Redditus bonorum episcopalium in terra Ruye conscripti, w drugim zaś Conscriptio siliginis episcopalis in terra Ruye, ujęte według okręgów wójtowskich ${ }^{3}$. Trzecim dokumentem będzie lustracja nowomarchijska, sporządzona w $1337 \mathrm{r}$. $\mathrm{z}$ nakazu nowego margrabiego Ludwika I Starszego Wittelsbacha ${ }^{4}$. Nie obejdzie się bez cytowania innych źródel.

Wskazane dokumenty różni oczywiście pochodzenie $\mathrm{z}$ oddalonych od siebie terytoriów, których rzeczywistość była odrębna, ale też łączy obraz organizacji zarządu terytorialnego. Różnica chronologiczna między nimi obejmuje raptem 23 lata, okoliczności zaś, w których powstały, są bardzo podobne. Biorąc pod uwage daty rugijskie 1314 i 1318 r., można powiedzieć, że dyplomy sporządzone zostały w przeddzień wygaśnięcia dynastii Wisławów i przejęcia państwa rugijskiego przez Gryfitów, co stało się w 1325 r. Lustracja znów Ludwika I Starszego została zarządzona i przeprowadzona w 1337 r., to jest w 17 lat od wygaśnięcia dynastii askańskiej, która obszary trans Oderam zdobyla. Wszystkie więc te trzy pomniki mogą uchodzić za rodzaje protokołów zdawczo-odbiorczych, sporządzonych we właściwym czasie.

Wspomniane dokumenty dotyczą dochodów i stanu posiadania księcia, margrabiego i biskupa, które szczegółowo wyliczają. Interesują nas w przedstawianym studium tylko podziały terytorialne $\mathrm{i}$ struktury władzy $\mathrm{w}$ terenie, zwłaszcza te, które będąc na Rugii $\mathrm{i}$ w Brandenburgii, nie wystąpily w źródłach zachodniopomorskich, choć można by się ich tam również spodziewać.

Problematyka dochodów książęcych, marchijskich czy biskupich bogato występująca w badanych źródłach, ze względu na swą obszerność nie nadaje się do przedstawienia $w$ artykule, gdyż przerasta go rozmiarami. Należności wspomnianych podmiotów ujęli autorzy spisów w odniesieniu do wsi należących do określonych jednostek podziału terytorialnego, $i$ to właśnie interesuje autora.

2.1. Wykaz sporządzony w $1314 \mathrm{r}^{5}$ przez rycerza $\mathrm{z}$ Brunświku przedstawia dokładnie dochody książęce $\mathrm{z}$ wyspy Rugii, płynące $\mathrm{z}$ bedy (praecaria), kar sądowych (excessus), danin zbożowych (redditus annonae) i drobiowych (redditus pullorum), i czyni to według okręgów zwanych konsekwentnie

\footnotetext{
${ }^{2}$ Pommersches Urkundenbuch [dalej: PU] V 2918.

${ }^{3}$ PU V 3234.

4 Das Neumärkische Landbuch Markgraf Ludwig's des Aelteren von Jahre 1337, Nach einer neuaufgefundenen Handschrift des vierzehten Jahrhunderts mitgetheilt von Dr. Gollmert, Frankfurt a/O. 1862, ss. 32.

${ }^{5}$ PU V 2918.
} 
ziemiami (terrae). Odnajdujemy przeto ziemie: Witowia, Patzig, Bergen, Garz, Rambin, Gingst, Schaprode i Jasmundię. Każda z tych ziem obejmowała przeciętnie około 30 wsi. Wyliczono dokładnie ilości łanów w poszczególnych miejscowościach (od 0,5 do 27) i należne panującemu kwoty. Dla każdej ziemi podsumowano liczbę łanów i przypadające księciu dochody.

2.2. Conscriptio siliginis epicopalis in terra Ruye z $1318 \mathrm{r}^{6}{ }^{6}$ uzupełniła spis rycerza z Brunświku przez wyodrębnienie jeszcze jednego okręgu $w$ Streu, ale nade wszystko przez odmienne nazewnictwo jednostek terytorialnych, będących przedmiotem naszego zainteresowania. Wszystkie zostały nazwane wójtostwami (advocatiae). Wójtostwo w Bergen, będące dość centralnym punktem wyspy, nazwano mianem advocatia dicta gharde. Od tego też wójtostwa zaczyna się wspomniany spis, podczas gdy w 1314 r. zajmuje ono jako terra dopiero trzecie miejsce w wykazie. Wójtostwo jasmundzkie, oblane niemal $\mathrm{z}$ każdej strony woda $\mathrm{z}$ wyjątkiem dwóch przesmyków lączących je $z$ wyspą, przedstawiono w 1318 r. jako advocatia terrae, czyli landwójtostwo. Inne określono po prostu jako advocatia. Do spisu biskupiego wprowadzono też najniższą jednostkę administracyjną Kościoła - parafię (parrochia). Nie wystąpila ona w wójtostwach Bergen, Gingst, Streu i Rambin, które wobec tego były najpewniej jednoparafialne. Pozostałe zostały spisane z parafiami, których w wójtostwach Jasmundii było dwie, w Patzig i Schaprode najpewniej po trzy, w Garz - aż sześć.

Rugia - wyspa o powierzchni $926 \mathrm{~km}^{2}$ - dzieliła się na dziewięć okręgów, zwanych w 1314 r. ziemiami, a w 1318 r. wójtostwami, i składała się najpewniej z 16 parafii. Wójtostwo obejmowało więc przeciętnie około $102 \mathrm{~km}^{2}$, dlatego określone jest jako niewielkie. Terminy wyróżniające Bergen i Jasmundię określeniami advocatia dicta gharde czy advocatia terrae nie stanowią zapewne próby ich wyróżnienia wśród tego typu okręgów, skoro $w$ akcie $1318 \mathrm{r}$. okazało się, iż Bergen było $\mathrm{z}$ pewnością tylko jedną parafią, Jasmundia zaś miała ich niewiele więcej, bo dwie. Oba dokumenty (1314 i 1318 r.) stanowią ważne źródła dla historii osadnictwa, skarbowości i dochodów Kościoła na wyspie?

2.3. Lustracja nowomarchijska Ludwika I Starszego z 1337 r. stanowi obszerniejszy dokument, w którym spisane zostały istniejące i opustoszałe wsie, z podaniem liczby łanów, także działających w nich młynów, karczem itp., oraz obszary leśne $\mathrm{i}$ wodne. Nie zapomniano również o bogatych władztwach patrymonialnych Wedlów i Grutherów. Brakuje natomiast

\footnotetext{
${ }^{6}$ PU V 3234.

${ }^{7}$ PU V 2918, 3234. Oba dokumenty są zbliżone pod względem objętości. W PU V zajmują każdy po 9 stron druku (s. 191-199, 408-416).
} 
- poza lanami proboszczowskimi po wsiach - latyfundiów kościelnych. Spis ułożono według obszarów związanych $\mathrm{z}$ ośrodkami grodowo-miejskimi, do których należały: Golenice, Lipiany, Myślibórz, Barlinek, Gorzów Wielkopolski, Strzelce Krajeńskie, Choszczno, Świdwin, Pełczyce, Zlocieniec, Danków, Kalisz Pomorski i zagadkowy Bentin polożony w ziemi wałeckiej. Jednostki terytorialne otrzymały nazwę ziem - terrae. Pominięto natomiast także inne civitates, oppida czy castra, które najwidoczniej z podziałem na ziemie nie były na razie związane (np. Trzcińsko, Recz, Ińsko, Moryń itp.). Obszary leśne (merica) i wodne (stagna) znalazły się w ostatniej części lustracji. W ich ramach odnaleźć można 89 osad leśnych i kilka miast $\mathrm{z}$ określonymi obowiązkami na rzecz margrabiego $\mathrm{z}$ powodu posiadania lasów. Wśród użytkowników lasów znalazły się Myślibórz i Barlinek. Dla badań nad osadnictwem w Nowej Marchii dzieło Ludwika I Starszego ma duże znaczenie, ale stwarza niebezpieczeństwo polegające na niekiedy podwójnym występowaniu niektórych osad pod nieco zmodyfikowaną nazwą, zwłaszcza gdy chodzi o tę część tekstu, która notuje ziemie, a nie lasy. Niewątpliwie pod względem zarządu ostatnie musialy wiązać się z ziemiami; lustracja nie pozwala o tym rozstrzygnąć. Podział Nowej Marchii na terrae został przez Ludwika I Starszego na tyle sprecyzowany, że umożliwilby z pewnością wykreślenie mapy administracyjnej tej prowincji brandenburskiej.

Zauważmy, iż 13 wyróżnionych obszarów zawierało 290 miejscowości (przeważnie wsi) zaludnionych, lecz w części też opustoszałych, co sprawiało, iż przeciętnie na każdą ziemię wypadać mogły około 22 wsie. Wittelsbachowskich terrae nie można określić mianem wielkich. Nawet, gdy założymy konieczność ich związku z obszarami leśnymi czy wodami, to najwyżej poszerzymy ich obszar, lecz nie pomnożymy osad. Z policzonych ziem, młynów, karczem, lasów i wód lustracja dokładnie określiła rozmiar świadczeń należnych margrabiemu brandenburskiemu. Poza podziałami na parafie znajdujemy w tym dokumencie brandenburskim prawie wszystko, co udało się skonstatować $w$ dwóch poprzednio przedstawionych aktach. Dodajmy, że ani powołane tu źródła rugijskie, ani lustracja nowomarchijska nie dotyczyły całości państw zainteresowanych dynastii, gdyż Wisławowie rządzili też na kontynencie, a margrabiowie brandenburscy bynajmniej nie tylko w Nowej Marchii. Dyplomy określają nazwy jednostek terytorialnych mianem terra (1314 r. i 1337 r.), a także advocatia dicta gharde, advocatia, advocatia terrae, parrochia (1318 r.). Parafie byly okręgami terytorialnymi kościoła, obejmującymi średnio 18 wsi (liczba absolutna wsi przynależących do parafii wahała się od dziewięciu do 36 - Patzig, Sagharde). Słuszne więc może się wydawać przypuszczenie, że wójtostwo w Bergen (38 wsi), Gingst wraz z wyspa Ummanz (36 wsi), Streu (49 wsi), Schaprode (28 wsi) i Rambin (36 wsi) mogły być kościelnie jednoparafialne. Parafie zresztą nas 
tu wprawdzie nie zajmują, lecz wyglądają interesująco $w$ zastawieniu $\mathrm{z}$ ziemiami z dokumentów z lat 1314 r. i 1337 r.

3. Studia nad Nową Marchią zmuszają widzieć na samym początku jej istnienia polską kasztelanię lubuską odstąpioną ostatecznie w latach 1249/50 przez Bolesława Rogatkę arcybiskupom magdeburskim i margrabiom brandenburskim $z$ dynastii askańskiej. Składala się ona wtedy z ziemi kostrzyńskiej i kinickiej, i jako prawdziwy łup niemiecki, od dawna przez sąsiadów zaodrzańskich upragniony, pozwoliła Niemcom na przekroczenie granicznej dotąd Odry, co stanowiło ogromną groźbę dla Polski i Pomorza Zachodniego. Nie wchodząc w szczegóły tych zdarzeń, odnajdujemy w zakresie zarządu terytorialnego te same elementy - podstawowy podział na ziemie, których struktura osiedleńczo-prawno-ustrojowa nie wygląda w źródłach tak jasno, jak $w$ przedstawionych wyżej dokumentach, ale fakt istnienia jest niewątpliwy ${ }^{8}$.

Z nowym władztwem politycznym, które gwałtownie rozszerzało się na wschód, zmierzając wzdhuż dolnej Warty i Noteci w kierunku Słupska i Gdańska, przyszedł także nowy model zarządu terytorialnego. Terra Transoderana wciskała się ostrym klinem $w$ terytoria pogranicza zachodniopomorsko-wielkopolskiego; otrzymywała więc w tradycji ustrojowej fragmenty polskich kasztelanii i zachodniopomorskich landwójtostw, czego marchia tolerować nie mogła. Organizowano je więc naprędce w nowe landwójtostwa zależne od margrabiego i lokowano $w$ miejscowościach, które się do tego $\mathrm{z}$ grubsza nadawały. Powstało $\mathrm{w}$ ten sposób landwójtostwo chojeńskie, naddrawskie, myśliborsko-gorzowskie, świdwińskie, lubuskie i frankfurckie. Okres askański do 1319 r. przyniósł też sześć lokacji miejskich (Gorzowa Wielkopolskiego - przeciwwagi polskiego Santoka - w 1257 r., Barlinka w 1278 r., Drawska w 1303 r., Kalisza Pomorskiego w 1303 r., Wałcza w 1303 r. i Shupska w 1310 r.). Frankfurt nad Odrą, lokowany w 1253 r., miał znaczenie jako przeciwwaga Lubusza, przede wszystkim dla Ziemi Torzymskiej, która powstawala niemal równolegle z Nową Marchią, choć jako Land Sternberg była od niej odróżniana. Ograniczona liczba lokacji miejskich nie oznacza bynajmniej opanowywania przez Brandenburgię ziem bezludnych, skoro do momentu wymarcia Askańczyków (1319/20 r.) naliczyć tu można 46 miejscowości określanych mianem oppidum, civitas, castrum (33 w Nowej Marchii, $13 \mathrm{w}$ Ziemi Torzymskiej) ${ }^{9}$. Stawia to pod znakiem zapytania rolę rozwojową czynnika brandenburskiego $w$ tych stronach.

\footnotetext{
${ }^{8}$ J. Walachowicz, Geneza i ustrój polityczny Nowej Marchii do poczqtków XIV w., Prace Komisji Historycznej PTPN, t. XXXI, Warszawa-Poznań 1980, s. 22-32.

Ibidem, s. 80.
} 
Tereny nowomarchijskie otrzymały pod rządami askańskimi pewną ważną zdobycz, którą był pokój. Dotąd były obszarem ustawicznych walk wielkopolsko-zachodniopomorskich, marchia zaś broniła swych granic konsekwentnie, co umożliwiło spokojniejszy byt. Ludność miejscowa była jednak dość niepewna politycznie i zróżnicowana etnicznie, co wymagało specjalnej czujności państwa, realizowanej przez rozbudowę aparatu zarządu lokowanego bliżej terenu: tzw. mas ludowych. Sprawa ta ujawnila się szczególnie po śmierci margrabiego Waldemara - tęsknotą za wymarłą dynastią, pojawieniem się Waldemara Samozwańca i niepokojów, które razem wzięte skłoniły pierwszego margrabiego z nowej dynastii Wittelsbachów bawarskich, Ludwika I Starszego, do sporządzenia lustracji w 1337 r., którą przedstawiono wyżej. Znamienne, że w miejsce sześciu lub pięciu (wspomniany Frankfurt nad Odrą) lokacji miejskich stwierdzonych do 1319 r. tzw. Landbuch (lustracja) wykazal w Nowej Marchii (już bez Ziemi Torzymskiej) 13 ziem i kilka obszarów leśnych ${ }^{10}$. Władza zeszła niżej, lecz Ludwik I Starszy nie zdradzil, kto na szczeblu ziem ją sprawowal. Sprawę ujawnily dopiero źródła szczegółowsze, jakimi są liczne, choć trudno dostępne i mało krytycznie wydane drukiem, dokumenty brandenburskie ${ }^{11}$. W czasach Wittelsbachów i Luksemburgów - jak świadczą o tym ówczesne źródła - nastąpil gwałtowny wzrost ośrodków władzy lokalnej - do 22 jednostek. Ich siedziby dla prawoodrzańskiego władztwa brandenburskiego znajdowały się w: Barlinku, Chojnie, Choszcznie, Dankowie, Dobiegniewie, Drawsku, Ińsku, Frankfurcie nad Odrą, Gorzowie Wielkopolskim, Kaliszu Pomorskim, Lipianach, Lubuszu, Mieszkowicach, Moryniu, Myśliborzu, Ośnie, Reczu, Strzelcach Krajeńskich, Sulęcinie, Świdwinie, Torzymiu, Trzcińsku. Okręgi skupione wokół tych miejscowości zwano wójtostwami (advocatiae), z czego można domniemywać, że na ich czele stali wójtowie; do roku 1402 odnalazłem ich 47. Landwójtostwa nowomarchijskie nie funkcjonowały jednak wcale jako tak drobne, jakby można sobie wyobrażać na podstawie przytoczonej wyżej listy ich siedzib. Powstawały bowiem od połowy XIV w. przez powierzanie jednej osobie, na ogół więcej niż jednego mikrowójtostwa, czasami nawet trzech lub czterech kompletowanych $\mathrm{w}$ przeróżnych ze-

${ }_{10}$ Das Neumärkische Landbuch..., s. 11, 14, 16, 19, 20, 22, 24, 26, 28.

${ }^{11}$ Codex Diplomaticus Brandenburgensis Sammlung der Urkunden, Chroniken und sonstigen Quellenschriften für die Geschichte der Mark Brandenburg und ihrer Regenten, Hrsg. von A. Riedel, Bd. 1-35, Berlin 1838-1869 [dalej cytuję: Rdl, seria, tom, strona]. Mniej krytyczne i nie zawsze kompletne streszczenia zdarzeń nowomarchijskich znajdziemy w: Regesta Historiae Neomarchicae. Die Urkunden zur Geschichte der Neumark und des Landes Sternberg, in Auszügen mitgeteilt von Kletke, Abteilung I, Märkische Forschungen, Bd. 10, Berlin 1867 [dalej cytuje: Kletke i strona]. Sytuacje wszakże ratuje krytycyzm Regesten der Markgrafen von Brandenburg aus askanischen Hause, Hrsg. von H. Krabbo und G. Winter, Veröfentlichungen des Vereins für Geschichte der Mark Brandenburg, Lieferung I-XII, Leipzig-München-Berlin 1910-1955 [dalej cytuję: Krabbo i nr regestu]. 
stawieniach, np.: Myślibórz, Choszczno, Drawsko, Recz, Kalisz Pomorski w latach 1349-1354 ${ }^{12}$; Chojna, Trzcińsko, Drawsko, Recz, Choszczno w latach 1359-1362 ${ }^{13}$, itp.

W Nowej Marchii funkcjonowal również starosta generalny dla calej tej prowincji, stojący ponad landwójtami dzierżącymi 1-5 ziem, zwanych adwokacjami. Nazywano go: capitaneus lub advocatus Terrae Transoderanae, lub też z niemiecka Hauptmann czy Landeshauptmann. Reprezentował on margrabiego w Nowej Marchii i byl zapewne zwierzchnikiem landwójtostw. Do 1402 r. naliczyć można 16 nowomarchijskich namiestników margrabiego ${ }^{14}$.

4. Na koniec przyjrzyjmy się jeszcze ziemi, która rozdzielała oba porównywane przez nas władztwa polityczne - przede wszystkim Pomorzu Zachodniemu.

Pomorze Zachodnie dzieliło się zrazu na obszary zasiedlenia plemiennego, które zauważyli autorzy żywotów św. Ottona - Herbord, Ebon, Wolfger z Priefening. Według mapy współczesnej znajdowały się one zarówno po polskiej stronie Pomorza Zachodniego - w: Szczecinie, Wolinie, Kołobrzegu, Kamieniu Pomorskim i Pyrzycach, jak i po niemieckiej - w: Demmin (Dyminie), Wolgast (Wologoszczy) i Gützkow (Chockowie) ${ }^{15}$. Na bazie tego podziału powstawały kasztelanie, których sieć - odpowiednio rozbudowana i obsadzana wyłącznie przez Pomorzan - znalazła swe siedziby - znów według wspólczesnej mapy - po polskiej stronie Odry, w: Uznamie, Szczecinie, Wolinie, Kamieniu Pomorskim, Kołobrzegu, Białogardzie, Sławnie i Słupsku, oraz po niemieckiej: Barth (Bardzie), Gützkow (Chockowie), Demmin

12 Rdl. I 18, 19.

${ }_{13}$ Rdl. I 18: 137; 19: 27-28; 23: 88; Kletke 294, 297-298, 304.

14 J. W a la chowicz, Starostwo $w$ zarzqdzie terytorialnym Marchiae Transodernae do poczq̨tków $X V w .$, CPH 1962, t. XXXIV, z. 1, s. 22-30, 34-36.

${ }^{15} \mathrm{M}$. Sczaniecki, Glówne linie rozwoju feudalnego państwa zachodniopomorskiego, cz. I, CPH 1955, t. VI, z. 1, który określa je mianem feudalnych republik miejskich; i K. B u cze k, Targi i miasta na prawie polskim, Prace Komisji Nauk Historycznych, $\mathrm{nr}$ 11, Wrocław-Warszawa-Kraków 1964, który słuszniej niż poprzednik widzi w nich schyłkowe formy ustroju plemiennego. Nadto Monumenta Germaniae Historica, Scriptores, t. XII, Hannoverae 1856 (Leipzig 1925), s. 721-903; 1. XX, Hannoverae 1868, ed. R. Köpke, s. 697-771; Die Prüfeniger vita des Bischofs Otto von Bamberg zur 800-jährigen Gedenkfeier des Christentums in Pommern, hrsg. von A. Hofmeister, Greifswald 1924, s. LX, 116; Monumenta Poloniae Historica, t. II, Lwów 1872 (Warszawa 1961), s. 23-144 (ekscerpty do historii Polski), ed. A. Bielowski; najnowsze wydanie Żywotów św. Ottona według Wolfgera z Priefening (1966), Ebona (1969) i Herborda (1974) z uwagami J. Wikarjaka oraz ze wstępem i komentarzem K. Limana, jest dziełem poznańskich latynistów - Monumenta Poloniae Historica, Series Nova, t. VII, fasc. 1 (1966), fasc. 2 (1969), fasc. 3 (1979), Warszawa [dalej cyt. według potrzeby: Prief., Ebon, Herbord]. Nadto J. Wa 1 a chowicz, Die Otto-Viten als Quellen zur polnischen Geschichte im Mittelalter, 125. Bericht des Historischen Vereins Bamberg 1989 , s. $241-249$. 
(Dyminie), Groswin (Groźwinie), Wolgast (Wologoszczy) ${ }^{16}$. W efekcie powstania latyfundiów kościelnych, świeckich oraz rozwoju immunitetu i prawa niemieckiego dla miast i wsi, kasztelania zachodniopomorska upadła, a jej miejsce zajęlo przysposobione do nowych warunków i odpowiednio zniemczone landwójtostwo. Nowych okręgów landwójtowskich naliczyłem swego czasu na Pomorzu Zachodnim łącznie z terytoriami rugijskimi aż 19. Znajdowały one swe centra częściowo w starych, a czasem w nowych ośrodkach władzy terenowej, w: Uznamiu, Szczecinie, Kamieniu Pomorskim, Gryficach, Białogardzie, Szczecinku, Sławnie i Słupsku, oraz w będących dzisiaj po niemieckiej stronie Pomorza Zachodniego: Barth (Bardzie), Triebsees (Trzebudzicach), Stralsund (Strzalowie), Grimmen (Grzymiu), Loitz (Eosicach), Demmin (Dyminie), Stovenhagen (Stawnie), Treptow a D. (Trzebutowie nad Doleża), Anklam (Nakle), Ückermünde (Wkryujście), Wolgast (Wologoszczy) i Rügen (Rugia) ${ }^{17}$.

Warto zauważyć dość znamienne zjawiska. W miarę umacniania się władzy monarszej na Pomorzu Zachodnim, rosła liczba okręgów zarządu terytorialnego (osiem okręgów rodowo-plemiennych za Warcisława, 14 kasztelanii do początków XIII w., 19 landwójtostw do 1335 r. - nie licząc whadztw patrymonialnych świeckich i duchownych oraz miast obdarzonych przywilejami). W 1325 r. Pomorze Zachodnie objęło wprawdzie Rugię, co wpłynęło $z$ pewnością na liczbę okręgów zarządu, ale i tak odnosi się wrażenie, iż książę czy jego urzędnik systematycznie zbliżali się do zarządzanych. Niemniej ciekawa jest też uwaga, że zachodnie okręgi zarządu były $\mathrm{z}$ reguły mniejsze od wschodnich. $\mathrm{Na}$ zachodzie funkcjonowało 12 landwójtostw, podczas gdy na wschodzie Pomorza Zachodniego tylko siedem. Jak wythumaczyć te zjawiska? Jest to bez wątpienia temat do dalszych badań historyczno-ustrojowych, etnicznych i demograficznych.

5. Czyżby Advocatia dicta gharde, występujaca w 1318 r. jako określenie rugijskiej ziemi Bergen (Moncium w 1314 r.), na Rugii pozostać miała zagadką? Rycerz z Brunświku w $1314 \mathrm{r}$. termin terra umieścił tylko przy pierwszej spisywanej ziemi Wittow, biskup Roeskilde w 1318 r. nazwe gharde zastosował tylko przy pierwszej pozycji swego spisu, przy wójtostwie Bergen, inne określając tylko mianem advocatia ${ }^{18}$. Byłby to tylko przypadek? Nie sądzę. Myślę natomiast, że terminu zastosowanego w 1175 r. przez księcia pomorskiego Kazimierza I w dokumencie dla klasztoru w Grobi, któremu przekazal wieś ex burgwardio gozcouensi ${ }^{19}$, nie moge uznać za

\footnotetext{
16 J. Walachowicz, Landwójtostwo na Pomorzu Zachodnim - Ksztaltowanie sie zarzqdu terytorialnego $w$ dobie pokasztelańskiej, Prace Wydziału Prawa UAM, nr 18, s. 12-15.

17 Ibidem, s. 21-83.

${ }^{18}$ PU V 2918, 3234.

${ }^{19}$ PU I 66 (37).
} 
właściwy dla porównań z XIV w. Zresztą biskup kamieński Sygwin nazwał ziemię Gützkow (chockowska) prowincją w 1216 r., a od 1175 r. znani są kasztelani chockowscy (Jarygniew, Priba, Bartosz i Prenca) ${ }^{20}$. Nie mógl to być drobiazg terytorialny, skoro później w ręku Salzwedlów stał się hrabstwem Gützkow (chockowskim), o znamionach władztwa terytorialnego uznającego jednak zwierzchnictwo Gryfitów ${ }^{21}$. Hipoteza o dwustopniowym zarządzie terytorialnym, opartym na grodach-miastach, znajduje też wyraz w istnieniu rycerza z Brunświku, którego trudno uznać za ksiażęcego landrentmistrza, gdyż sporządził tylko spis dochodów z Rugii, pomijając pozostałe ziemie Wisławów ${ }^{22}$. Musial więc być kompetentny tylko w stosunku do wyspy. Niemało też źródeł świadczy o istnieniu landwójtów rugijskich ponad wójtami grodowymi. Zestawiliśmy ich $w$ innej pracy. Tytułowali się jako advocati terrae Ruyae, zaś od 1327 r. capitanei Ruyanorum insulae. Nieraz wykonywali też jurysdykcję nad okolicznymi względem dużej wyspy wysepkami Ummanz i Hiddensee ${ }^{23}$. Zatem określenia terra z 1314 r. i gharde z 1318 r. odnoszą się do wszystkich ziem ujętych $w$ obu spisach, a nie tylko do Witowii i Bergen.

Podobnie wyglądała sytuacja w Nowej Marchii. Lustracja Ludwika I Starszego z 1337 r. zupelnie niedwuznacznie wskazała na jej podzial na ziemie (terrae). Późniejszy rozwój, wzrost liczby wójtostw (advocatiae) - zapewne miniaturowych, skoro było ich aż 22 - potwierdza zdanie o skomplikowanym podziale terytorialnym, wyrosłym na tle obaw o utrate kontroli nad świeżo opanowanym siłą krajem. Powierzanie landwójtom po kilka takich mikrowójtostw pozwoliło utrzymać większe landwójtostwa $\mathrm{z}$ okresu askańskiego. Wittelsbachowie jednak, a także Luksemburgowie postawili nad nimi jeszcze starostów z tytułem capitanei Terrae Transoderanae, trans Oderam lub w nieco innym, często niemieckim brzmieniu Hauptmänner, Landeshauptmänner über Oder, $\mathrm{z}$ władzą namiestnika margrabiego.

Hierarchii w zarządzie terytorialnym nie można zauważyć na Pomorzu Zachodnim. Wytłumaczeniem może być długowieczny, pokojowy i samodzielny rozwój instytucjonalny tego kraju. Częste podziały dynastyczne zbliżały panującego $\mathrm{w}$ dostateczny sposób, do terenu, którym zarządzał. Rozwój procesów feudalizacyjnych i immunitetów niemal od początku pełnych sprawil, że rozczłonowane terytoria mogły być zarządzane w oparciu o dobra książęce przez landwójtów, którzy podlegali bezpośrednio monarsze. Inaczej wyglądała sytuacja $w$ państwie Wisławów rugijskich, którzy władali wyspami i terytoriami polożonymi na kontynencie. W artykule zajęliśmy się Rugią, stanowiącą tylko część - choć najważniejszą

\footnotetext{
${ }^{20}$ PU I 171 (107). Nadto J. W a l a ch o w i c $z$, Landwójtostwo..., s. 12.

${ }^{21} \mathrm{~J}$. W a la c h ow i c z, Landwójtostwo..., s. 84-86.

${ }^{22}$ PU V 2918.

${ }^{23}$ J. W a la ch ow ic z, Landwójtostwo..., s. 30-39.
} 
- księstwa. Rozczłonowanie tej wyspy na obszary poprzedzielane zatokami, zalewami itp. przeszkodami $w$ komunikacji, oraz zagrożenie od strony morza uzasadniały istnienie podlandwójtostw grodowych zwanych gharde, $i$ to jeszcze w XIV w. Nowa Marchia także wymagała hierarchii zarządzającej terenami. Było to może mniej potrzebne w okresie askańskim, bo Askańczycy dbali o nią jak o oko w glowie. Wittelsbachowie jednak i Luksemburgowie bardziej zainteresowani byli wielką polityką europejską, znacznie mniej samą Brandenburgią, a zwłaszcza jej najbardziej wschodnią częścią, jaką była Terra Transoderana - późniejsza Nowa Marchia. Pamiętać jednocześnie trzeba, że był to kraj świeżo zagrabiony Polsce i Pomorzu Zachodniemu i że oba te państwa o tym pamiętaly, czekając na możliwości rewindykacyjne. Wynikła stąd skądinąd zrozumiała konieczność sporządzenia lustracji i chyba także sensowny pomysł uruchomienia starostwa nowomarchijskiego, którego posiadacz troszczyłby się o spokój, bezpieczeństwo i całość tej prowincji. Zadania stawiane starostom przerastały ich siły, wewnątrz kraju wzrastały więc rozboje, niepokoje i gwałty, które uciszyli dopiero krzyżacy po 1402 r. Pojawily sie i straty terytorialne. Kazimierz Wielki potrafił bowiem w 1368 r. przebić kordon nowomarchijski na odcinku ziemi drawskiej i uzyskać bezpośrednie połączenie graniczne dla Polski z Pomorzem Shupskim - ważne dla obu krajów. Nowa Marchia poczuła się zagrożona.

W końcu podkreślić trzeba trudności badawcze występujące na każdym kroku w badaniach spraw brandenburskich. Należą do nich - poza nieporządnymi wydawnictwami źródeł - wieloznaczności terminologiczne w obu językach: lacińskim i niemieckim, jak w przypadku nazw terra i advocatus. Terminy te spotyka się bardzo często $w$ tym samym brzmieniu na różnych szczeblach hierarchii terenowej. Wójtowie urzędowali zasadniczo w miastach, nie można więc tym mianem określić urzędnika, który stał na czele advocatia dicta gharde, czy terra z lustracji Ludwika I Wittelsbacha i czasów nastepnych. Mikrowójtostwa podlegaly urzędnikom, których można by w końcu w źródłach znaleźć. Landwójtowie mieli przecież różnych pomocników: podwójcich, bedellów, pristawów itp. Któremu $\mathrm{z}$ nich jednak poddano najmniejsze wójtostwo - nie wiadomo. 